\title{
IS AUSTROPOTAMOBIUS PALLIPES A GOOD BIOINDICATOR?*
}

\author{
L. FÜREDER (1), J. D. REYNOLDS (2)
}

(1) University of Innsbruck, Institute of Zoology and Limnology, Technikerstr. 25, A-6020 Innsbruck, Austria.

E-Mail: leopold.fuereder@uibk.ac.at

(2) Department of Zoology, University of Dublin, Trinity College, Dublin 2, Ireland.

Reçu le 10 novembre 2004

Accepté le 18 mars 2004

Received November 10, 2004

Accepted March 18, 2004

\begin{abstract}
The use of indicators is among the most important and popular instruments of environmental control and nature conservation. Within the EU project "Craynet", integrated research projects and general discussions have been presented with the aim of monitoring European native crayfish as indicators of biodiversity. Underlying many presentations on crayfish was the implicit assumption that Austropotamobius species were bioindicators for good water quality. With this as background, the Round-table discussion at the meeting in Kilkenny opened with two general questions, (1) what is a bioindicator and how well do crayfish, and especially Austropotamobius pallipes, match this concept? and (2) are other concepts such as "surrogate species" (sensu CARO and O'DOHERTY, 1999) more appropriate? The suitability of $A$. pallipes to be classed as a bioindicator was questioned by discussing its general tolerance to pollution, and the roles played by eutrophication and organic enrichment, water chemistry, chemical pollutants, and habitat. The value of $A$. pallipes as a bioindicator still remains debated; we are aware of many studies and statements of varying objectivity from fairly good to poor examples defining this species as a good to weak bioindicator. It seems that $A$. pallipes has potential as a bioindicator, however, perhaps only when we are able to narrow and define its tolerance levels. One conclusion of this interesting discussion is that a much better keyword, instead of " bioindicator ", would be " flagship species ", not least because of their " cultural heritage " value.
\end{abstract}

Key-words: A. pallipes, bioindicator, water quality, habitat, flagship species.

\section{AUSTROPOTAMOBIUS PALLIPES EST-ELLE UN BIOINDICATEUR RECONNU ?}

\section{RÉSUMÉ}

L'utilisation des indicateurs figure parmi un des instruments les plus importants et des plus courants en ce qui concerne le contrôle environnemental et la conservation de la nature. Au sein du projet européen «Craynet », des projets de recherches intégrés sont présentés et des discussions générales conduites pour gérer les écrevisses européennes natives en tant qu'indicateurs de la biodiversité. A la suite de plusieurs présentations sur les écrevisses, le postulat implicite semble être qu'Austropotamobius est un bioindicateur d'une bonne qualité de l'eau. Partant de ce postulat, les discussions au cours de la table ronde à Kilkenny ont été ouvertes avec deux questions générales, (1) Qu'est ce qu'un

\footnotetext{
* Round-table discussion - convenor: Leopold Füreder (Austria); rapporteur: Roisin Lyons (Ireland).
} 
bioindicateur et comment les écrevisses, et en particulier Austropotamobius pallipes, peuvent bien correspondre à ce concept, et (2) y -a-t-il d'autres concepts plus appropriés comme par exemple "les espèces de substitution" (sensu CARO et O'DOHERTY, 1999) ? La question de l'aptitude d'A. pallipes en tant que bioindicateur a été soulevée en discutant de sa tolérance générale à la pollution, et du rôle de l'eutrophisation, de l'augmentation de la richesse organique, de la chimie de l'eau, des polluants chimiques et de l'habitat. La valeur d'A. pallipes en tant que bioindicateur reste toujours au cœur du débat ; nous sommes au courant des études et des rapports nombreux, dont l'objectivité est variable, depuis de très bons exemples jusqu'à des moins bons, définissant cette espèce comme un bioindicateur bon à faible. II semble qu'A. pallipes ait le potentiel pour être un bioindicateur, cependant seulement peut être quand nous serons capables de cerner et de définir ses niveaux de tolérance. Pour conclure ce débat intéressant, il a été suggéré que le mot clé " espèce amirale » à la place de «bioindicateur » serait bien meilleur mais aussi à cause de sa «valeur patrimoniale culturelle».

Mots-clés : $A$. pallipes, bioindicateur, qualité de l'eau, habitat, espèce amirale.

\section{INTRODUCTION}

There is an increasing requirement for suitable and robust bioindication methods for the assessment of anthropogenic impacts on aquatic ecosystems and the evaluation of restoration and management measures. This increasing need for methods to evaluate the actual state of ecosystems and to monitor their rate of change has promoted exploration of how communities of organisms may be used as indicator systems of anthropogenic environmental changes or as the basis for criteria to identify conservation priorities or restoration tools (ROSENBERG and RESH, 1993). Several methodologies have been developed in individual countries, ranging from the use of single species and species traits to guilds or multi-species levels (ROSENBERG and RESH, 1993; BARBOUR et al., 1996; USSEGLIO-POLATERA et al., 2000). In biological assessments of river quality, indices based on the abundance and/or richness of various taxonomic groups are normally used, such as aquatic invertebrates (e.g., MOOG and CHOVANEC, 2000) or fish (SCHIEMER, 2000). USSEGLIO-POLATERA et al. (2000) however, commented that the generalization of these indices to every type of running water has failed because of natural fluctuations in these groups under different ecoregional conditions. These authors stated that new synthetic expressions preserving more of the ecological information provided by macroinvertebrates are required. An alternative approach is to sample from a range of running-water microhabitats in the proportions observed in the habitat, in order to include species with a wide range of ecological requirements (see GRANDJEAN et al., 2003).

Due to their homotopic (solely aquatic) and benthic life form crayfish are necessarily dependent on specific features of the aquatic ecosystem. Habitat heterogeneity, water quality and lack of pollutants have been shown to enhance or ensure the survival of indigenous crayfish (e.g., FÜREDER et al., 2003; GRANDJEAN et al., 2003; TROUILHE et al., 2003). However there are also examples that showed in contrast crayfish to occur in several kinds of environmental conditions ranging from natural to degraded levels (e.g., DEMERS and REYNOLDS, 2003; FÜREDER et al., 2003).

Underlying many presentations on crayfish was the implicit assumption that Austropotamobius species were bioindicators for good water quality. With this as background, the Round-table discussion opened with two general questions:

(1) What is a bioindicator, and how well do crayfish, and especially Austropotamobius pallipes, match this concept?

(2) Are other concepts such as "surrogate" species" (sensu CARO and O'DOHERTY, 1999) more appropriate? 


\section{DISCUSSION}

Leopold Füreder (Austria) opened the discussion by introducing a number of definitions for a " bioindicator ". According to various authors, bioindicators are organisms that indicate the long-term interaction of several environmental conditions, but also react to a sudden change of important combinations of factors, or which indicate natural habitat/ site conditions. Other authors consider only those organisms that react to changes in the environment by alterations in their metabolism, activity, or other aspects of their biology, or that accumulate toxic substances.

Participants agreed that acceptance of a detailed description or definition of " bioindicator" was needed before discussing to what extent, if any, do A. pallipes and/or crayfish in general react to change in conditions? Relevant characteristics of a bioindicator were generally agreed as follows:

- clear taxonomy,

- wide or cosmopolitan distribution,

- occurrence in adequately high numbers,

- appropriately large body size and easy to find,

- low mobility (local indication),

- long life-span,

- well studied ecology,

- low genetic and ecological variability,

- suitability for laboratory experiments (optimal for being " actively " monitored),

- high sensitivity towards specific substances,

- high ability for quantification and standardization,

- bioaccumulation.

The question of bioindication thus needed to be addressed at different levels - cell and tissue responses, individual organism, population biology, species associations, assemblages or biocoenoses. Issues at stake, relevant to crayfish, considered for inclusion were water quality, eutrophication, acidification and river morphology, also government actions. It was further agreed that the question as to whether white-clawed crayfish accumulate materials, such as toxins, at rates related to their change or increase in the environment, would not be further discussed in this framework.

The meeting continued with members addressing the suitability of $A$. pallipes to be classed as a bioindicator and discussing a) its general tolerance to pollution, and the various roles of b) eutrophication and organic enrichment, c) water chemistry and chemical pollutants, and d) habitat. In a final round it was questioned whether $A$. pallipes or in general freshwater crayfish would be better considered as flagship species than bioindicators.

\section{a) Is $A$. pallipes a tolerant species?}

Julian Reynolds (Ireland) observed that $A$. pallipes acted as a fairly tolerant species in Northern Europe and the British Isles, but there appears to be a certain level of pollution at which they disappear.

Fernando Alonso (Spain) said that current distribution of crayfish in Spain has mostly been shaped by plague events, so the species is not necessarily an indicator of good water quality. Populations only exist in the mountains and headwaters where the plague has not reached. It is probably lost from lower quality waters (connected to main 
drainages) through plague, although David Holdich (UK) asked if its loss might be also due to intensive agriculture.

In contrast, Marina Paolucci (Italy) commented that in Campania (Southern Italy) A. pallipes was virtually absent in regions where there is little industry. Agriculture may be having an adverse affect. However, removal by people, e.g. fishing methods using chlorides, toxic substances etc. is the main reason for their disappearance. Francesca Gherardi (Italy) mentioned the general problem of water in Central Italy - through global warming, increasing summer droughts and human overuse. Temperature may also be a factor restricting distribution in lowland regions of Southern Europe.

\section{b) Eutrophication, organic enrichment}

Stephanie Peay (UK) believes that $A$. pallipes is not a good bioindicator. In the UK, populations survive in acid, peaty areas in the moorlands (though in low abundance) but also occur in eutrophic angling lakes and muddy canals in high abundance. They get by in a range of conditions up to a certain threshold and when this is exceeded the population crashes rapidly. Another reason why they are poor bioindicators is that they are slow colonisers, they need time to recover from a pollution incident or they may never recover. A bioindicator should show a graded response, not an on/off situation.

Lyons and Kelly-Quinn (2003) documented a decline in crayfish populations in a eutrophic stream, and LIBERATO et al. (2003) presented evidence of oxidative stress in enriched conditions. Both indicated sensitivity to eutrophication.

Leopold Füreder (Austria) commented that low levels of eutrophication were probably not detrimental. He stated that crayfish are present in the immediate outlet of lakes where there are increased nutrient levels, however further downstream they are not present. Temperature may also be a further factor where there is organic enrichment (e.g. downstream of a lake). The species (A. pallipes) is known as "Sumpfkrebs" in Carinthia (MACHINO and FÜREDER, 1996), from its occurrence in small swampy ponds. Stephanie Peay (UK) also mentioned that $A$. pallipes is known as the "Sewer Crab " in Switzerland, following LAURENT (1988).

Peter Sibley (UK) commented that low oxygen levels differed from organic pollution, and the latter from eutrophication. UK rivers were often eutrophic from diffuse fertiliser input, but not necessarily organically enriched. In the main UK system for monitoring invertebrate pollution, $A$. pallipes scored 8 on a 10-point scale because of its oxygen tolerance.

Frédéric Grandjean (France) mentioned that in the French IBGN index of invertebrates, A. pallipes was formerly included with good indicators such as Plecoptera, but is now deleted from this group because of its tolerance to eutrophication and acidity.

Przemyslaw Smietana (Poland) commented that eutrophication showed a continuum especially in lakes, involving acidification. Stephanie Peay (UK) said that crayfish tolerate acid conditions and low $\mathrm{CaCO}_{3}$-hardness better if mild enrichment is also present. David Holdich (UK) said that calcium was essential, at a fairly stable minimum level of $2 \mathrm{mg} \mathrm{Ca}^{2+}$ per litre, as in Huddersfield (UK). Thus, even though $5 \mathrm{mgl}^{-1}$ has been considered the cut-off point, crayfish may prefer this level but can survive below it.

\section{c) Chemistry and chemical pollutants}

Stephanie Peay (UK) said that there was a need to define the threshold of limiting factors such as $\mathrm{DO}, \mathrm{NH}_{4}$, acid, chemical toxins, etc., at which crayfish populations start 
to crash. Population collapses may be followed by slow recolonisation, but recovery may not occur before another limiting event takes place.

In South Tyrol insecticides and fertilizers seem most dangerous to crayfish (Leopold Füreder, Austria). David Holdich (UK) commented that unpublished theses showed fertilisers were only a problem when combined with low oxygen. The effect of fertilizer is indirect, it causes increased growth of algae and an $\mathrm{O}_{2}$ sag downstream. Insecticides are rarely measured until after a catastrophic event, and can therefore rarely be implicated in a mortality or loss. However, Pyrethroids are known to be lethal, also such as lindane (which bioaccumulates) or heavy metals.

Andréanne Demers (Ireland) commented that in her laboratory work with $\mathrm{NH}_{3}$ and DO low oxyen proved not to be a problem, but combined with low $\mathrm{NH}_{3}$ had some sublethal effects. She suggested that the combined effect of ammonia and low $\mathrm{O}_{2}$ might trigger an adverse response by $A$. pallipes. Population crashes may be precipitated by low oxygen in association with something else.

\section{d) Habitat}

Manfred Pöckl (Austria) said that $A$. pallipes was a better indicator of river habitat characteristics than for water quality. High heterogeneity and high numbers of refuges encouraged colonisation by white-clawed crayfish. Stephanie Peay (UK) commented on the habitat diversity required to support crayfish, and the adverse impacts of trampling through loss of refuges.

Marina Paolucci (Italy) agreed that crayfish were excellent indicators of habitat quality. The interference with insecticides is because impaired rivers are in heavily used landscapes. She also noted that the Italian Environmental Agency has produced a computer correlation which can be used to predict crayfish occurrence in relation to habitat. However, David Holdich (UK) and Stephanie Peay (UK) disputed its usefulness on a wider scale.

Leopold Füreder (Austria) reiterated that based on several findings in Austria and Northern Italy (South Tyrol), crayfish are good indicators of the habitat. David Holdich (UK) disagreed, because he has seen them in all habitat conditions. He referred to a case where crayfish would not have been expected - the mid channel substrate consisted of sand and sediment but yielded 5 or more per trap. Julian Reynolds (Ireland) concurred with this, as from his experience, they occur in many lakes which lack rocks and aquatic vegetation apart from Chara. Thus, perhaps bankside habitats are important, rather than instream or midlake conditions.

\section{e) Freshwater crayfish - bioindicators or flagships?}

Julian Reynolds (Ireland) stated that crayfish are a suitable "heritage species" as they are large, visible, they have high socio-economic value and can be ranked along with other heritage species like otter, salmon and freshwater pearl mussel (Margaritifera margaritifera). He questioned whether $A$. pallipes is as good an indicator of water quality as the salmon. Does $A$. pallipes make a better flagship species than, for example the otter, which is not found everywhere? Otters, being very susceptible to persistent insecticides, declined precipitously across Europe but are now making a comeback in many regions.

Stephany Peay (UK) said that Crayfish make a good flagship species, as otter, for example, are difficult to see. In contrast crayfish are easy to see and find and this will enthuse people. John Lucey (Ireland) mentioned at this point that another possible " flagship " species, Margaritifera is classified as a Group A species in the Irish EPA Water quality Index, whereas $A$. pallipes is classified in Group C (the tolerant class) as it is much more tolerant to organic pollution. 
Leopold Füreder (Austria) again agreed that $A$. pallipes was not a suitable indicator of organic enrichment or eutrophication, and Stephanie Peay (UK) reiterated that it is a good indicator of habitat quality. A lack of complexity in banks can have adverse affects.

Mary Kelly-Quinn (Ireland) felt that it was perhaps too early to discuss the indicator potential of $A$. pallipes. In Ireland it mirrors salmonids in their response to pollution pressures in that populations persist even in the presence of moderate pollution but at a certain point they are, like salmonids, eliminated. Indicators may represent a grade of impact. Further study is needed to grade the response of $A$. pallipes to various pollution pressures. Julian Reynolds (Ireland) agreed that $A$. pallipes exhibits a broad level of tolerance. He feels it is a good indicator of a decline below an acceptable level of enrichment.

Andreanne Demers (Ireland) observed that population changes in A. pallipes may indicate a change in habitat quality rather than saying whether a site has good or poor habitat. They are found at water quality levels 1 and 2 (good to moderate) in a 4-point scale. Stephanie Peay (UK) reiterated that we don't understand enough about natural fluctuations over time, long recognised and perhaps disease-related.

Ferdia Marnell (Ireland) commented that from what he had heard, an objective viewpoint must be that $A$. pallipes is a poor bioindicator of either water or habitat quality. It has more potential as a flagship species.

\section{CONCLUSION}

Leopold Füreder (Austria) concluded that since we see some response in crayfish to environmental degradation it seems that $A$. pallipes has potential as a bioindicator. However, perhaps this can only be realised when we are able to narrow and define its tolerance levels.

The value of $A$. pallipes as a bioindicator is still debated, we are aware of many studies and statements of varying objectivity from fairly good to really bad examples defining this species as a good to weak bioindicator. One important suggestion was to narrow down its potential tolerance values. We recognized a lack of knowledge of the effect of factors or the combined effect of two (or more) factors, but also a great lack of experimental studies. In this context, the work of LIBERATO et al. (2003) is interesting. We have not addressed the potential of using crayfish genetics as bioindicator, e.g., to detect impairments of the longitudinal dimension of rivers (see SOUTY-GROSSET et al., 2003). Considering the tenor of this interesting discussion, a much better keyword instead of " bioindicator " would be " flagship species", especially because of their "cultural heritage" value. In this sense crayfish may act as a "surrogate species" (see also FÜREDER et al. 2003) of particular use in biological conservation.

\section{REFERENCES}

BARBOUR M.T., GERRITSEN J., GRIFFITH G.E., FRYDENBORG R., MCCARRON E., WHITE J.S., BASTIAN M.L., 1996. A framework for biological criteria for Florida streams using benthic macroinvertebrates. Journal of the North American Benthological Society, 15, 185-211.

CARO T.M., O'DOHERTY G., 1999. On the use of surrogate species in conservation biology. Conservation Biology, 13, 805-814.

DEMERS A. and REYNOLDS J.D., CIONI A., 2003. Habitat preference of different size classes of Austropotamobius pallipes in an Irish rivers. Bull. Fr. Pêche Piscic., 370$371,127-137$. 
FÜREDER L., OBERKOFLER B., HANEL R., LEITER J., THALER B., 2003. The freshwater crayfish Austropotamobius pallipes in South Tyrol: Heritage species and bioindicator. Bull. Fr. Pêche Piscic., 370-371, 81-95.

GRANDJEAN F., MOMON J., BRAMARD M., 2003. Biological water quality assessment of the white-clawed crayfish habitat based on macroinvertebrate communities: usefulness for its conservation. Bull. Fr. Pêche Piscic., 370-371, 115-125.

LAURENT P.J., 1988. Austropotamobius pallipes and A. torrentium, with observations on their interactions with other species in Europe. In: HOLDICH D.M., LOWERY R.S. (eds). Freshwater crayfish, biology, management and exploitation, 341-364. Chapman and Hall, London.

LIBERATO C., DI CRISTO C, DE LUISE G., DI COSMO A., PAOLUCCI M., 2003. Preliminary evidence of an oxidative stress in freshwater crayfish Austropotamobius pallipes italicus. Bull. Fr. Pêche Piscic., 370-371, 151-155.

LYONS R., KELLY-QUINN M., 2003. An investigation into the disappearance of Austropotamobius pallipes (Lereboullet) populations, in the headwaters of the Nore River, Ireland, and the correlation to water quality. Bull. Fr. Pêche Piscic., 370-371, 139-151.

MACHINO Y., FÜREDER L., 1996. Der Kärntner „Sumpfkrebs“ im Gailtal. - Österreichs Fischerei, 49 (4), 93-97.

MOOG O., CHOVANEC A., 2000. Assessing the Ecological Integrity of Rivers: Walking the line among ecological, political and administrative interests. In : JUNGWIRTH M., MUHAR S., SCHMUTZ S. (Eds), Assessing the Ecological Integrity of running waters, Hydrobiologia, 422/423, pp. 99-109.

ROSENBERG D.M., RESH V.H., 1993. Freshwater biomonitoring and benthic macroinvertebrates. Chapman and Hall, New York, London, pp. 1-488.

SCHIEMER F., 2000. Fish as indicators for the assessment of the ecological integrity of large rivers. In: JUNGWIRTH M., MUHAR S., SCHMUTZ S. (Eds), Assessing the Ecological Integrity of running waters, Hydrobiologia, 422/423, pp. 271-278.

SOUTY-GROSSET C., GRANDJEAN F., GOUIN N., 2003. Involvement of genetics in knowledge, stock management and conservation of Austropotamobius pallipes in Europe. Bull. Fr. Pêche Piscic., 370-371, 167-178.

TROUILHE M.C., RICARD F., PARINET B., GRANDJEAN F., SOUTY-GROSSET C., 2003. Management of the white-clawed crayfish (Austropotamobius pallipes) in Western France : abiotic and biotic factors study. Bull. Fr. Pêche Piscic., 370-371, 97-114.

USSEGLIO-POLATERA P., BOURNAUD M., RICHOUX P., TACHET H., 2000. Biomonitoring through ecological traits of benthic macroinvertebrates: how to use species trait databases? In: JUNGWIRTH M., MUHAR S., SCHMUTZ S. (Eds), Assessing the Ecological Integrity of running waters. Hydrobiologia, 422/423, pp. 153-162. 